\title{
T-2 TOXIN: INCIDENCE AND TOXICITY IN POULTRY
}

\author{
Marijana SOKOLOVIĆ ${ }^{1}$, Verica GARAJ-VRHOVAC ${ }^{2}$, and Borka ŠIMPRAGA ${ }^{1}$ \\ Poultry Centre of the Croatian Veterinary Institute', Institute for Medical Research and Occupational Health², \\ Zagreb, Croatia
}

Received in June 2007

Accepted in February 2008

\begin{abstract}
T-2 toxin is the most toxic type A trichothecene mycotoxin. It is the secondary metabolite of the Fusarium fungi, and is common in grain and animal feed. Toxic effects have been shown both in experimental animals and in livestock. It has been implicated in several outbreaks of human mycotoxicoses. Toxic effects in poultry include inhibition of protein, DNA, and RNA synthesis, cytotoxicity, immunomodulation, cell lesions in the digestive tract, organs and skin, neural disturbances and low performance in poultry production (decreased weight gain, egg production, and hatchability). Concentrations of T-2 toxin in feed are usually low, and its immunosuppressive effects and secondary infections often make diagnosis difficult. If at the onset of the disease, a change in diet leads to health and performance improvements in animals, this may point to mycotoxin poisoning. Regular control of grain and feed samples is a valuable preventive measure, and it is accurate only if representative samples are tested. This article reviews the incidence and toxic effects of T-2 toxin in poultry.
\end{abstract}

KEY WORDS: cytotoxicity, genotoxicity, trichothecene mycotoxins

$\mathrm{T}-2$ toxin is a member of a large group of fungal metabolites with the same basic chemical structure, called trichothecene mycotoxins. There are nearly 190 closely related chemical compounds in the group of trichothecene toxins, named after the first isolated trichothecene molecule trichothecin (1-6). The basic structure of these molecules is tetracyclic, with a sesquiterpenoid 12,13-epoxytrichothec-9-ene ring system $(1,7,8)$. They are divided in four types (A-D), depending on the presence (macrocyclic trichothecenes) or absence (non-macrocyclic trichothecenes) of macrocyclic ring between $\mathrm{C}-4$ and C-15, and further according to the number of hydroxyl and acetoxy groups attached to a carbon atom.

T-2 toxin was first isolated from the mould $F$. tricinctum (F. sporotrichoides) $(7,9)$. It belongs to non-macrocyclic type A trichothecenes. Its chemical structure is characterised by a hydroxyl $(\mathrm{OH})$ group at the $\mathrm{C}-3$ position, acetyloxy $\left(-\mathrm{OCOCH}_{3}\right)$ groups at $\mathrm{C}-4$ and $\mathrm{C}-15$ positions, atom of hydrogen at $\mathrm{C}-7$ position and an ester-linked isovaleryl $\left[\mathrm{OCOCH}_{2} \mathrm{CH}\left(\mathrm{CH}_{3}\right)_{2}\right]$ group at the C-8 position (Figure 1) (10). It is produced primarily by Fusarium species $F$. acuminatum, $F$. nivale, F. oxysporum, F. poae, F. sporotrichoides, and $F$. solani. However, moulds belonging to other genera (Trichoderma sp., Myrothecium sp.) were also found to produce T-2 toxin $(1,4,7,9-14)$.

\section{Chemical characteristics}

T-2 toxin is a non-volatile, low-molecular-weight compound (MW 466.52) insoluble in water and petroleum ether, but highly soluble in acetone, ethyl-acetate, chloroform, dimethyl sulphoxide, ethyl alcohol, methyl alcohol and propylene glycol (15). It is highly resistant to heat and UV light $(11,16)$. Therefore, it is not inactivated in food production and processing or by autoclaving. T-2 toxin is inactivated by heating at $200^{\circ} \mathrm{C}$ to $210^{\circ} \mathrm{C}$ for $30 \mathrm{~min}$ to $40 \mathrm{~min}$, or by soaking in sodium hypochlorite - sodium hydroxide solution for at least four hours (11). Some bacteria and moulds have the ability to transform and detoxify $\mathrm{T}-2$ toxin $(17,18)$. 


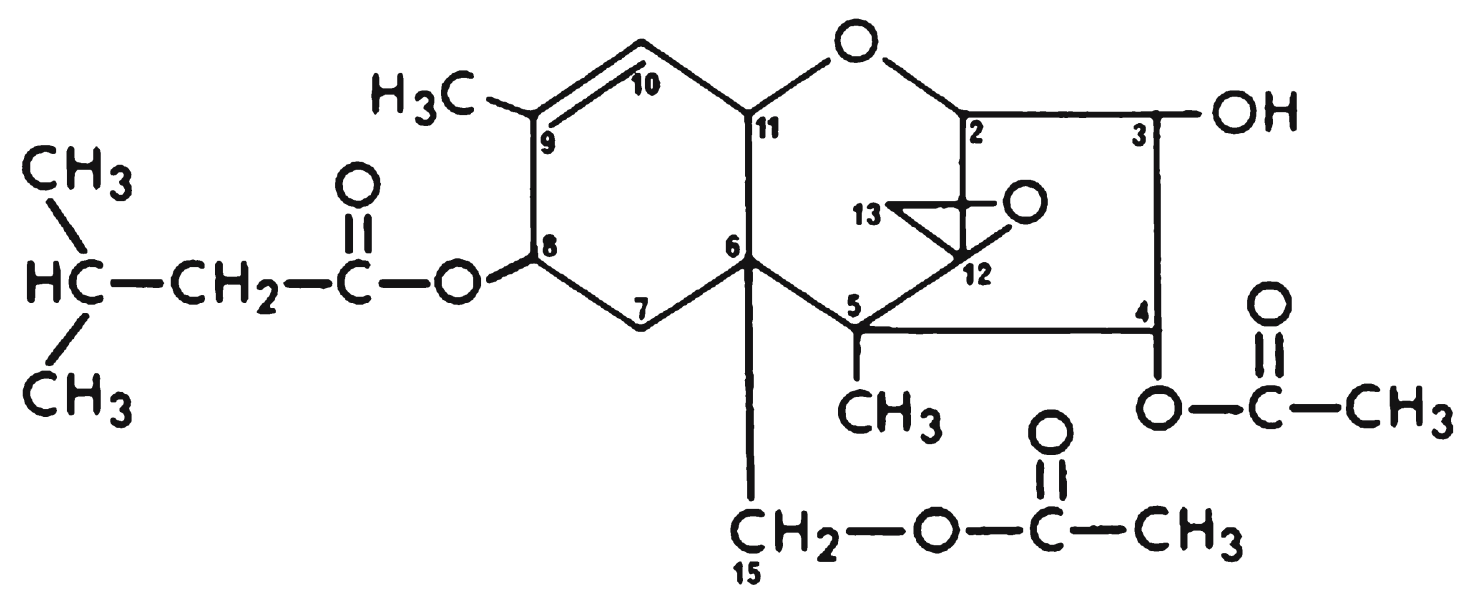

Figure 1 Chemical structure of T-2 toxin. (1)

\section{Natural occurrence in grain and feed}

Although reported natural occurrence of T-2 toxin and related mycotoxins shows their worldwide presence, they are predominant in tropical and subtropical regions. Warm and moist weather conditions favour plant infection with Fusarium spp., while improper storage and handling of grain with high moisture content can lead to T-2 toxin contamination $(19,20)$. In short, the most important factors that influence T-2 toxin production are weather conditions, grain defects and moisture content (13\% to $22 \%$ ). T-2 toxin is produced at a wide temperature range $\left(0^{\circ} \mathrm{C}\right.$ to $32^{\circ} \mathrm{C}$ ), with maximum production at temperatures below $15{ }^{\circ} \mathrm{C}(13,21-23)$. Namely, F. sporotrichioides has a low optimal temperature $\left(6^{\circ} \mathrm{C}\right.$ to $\left.12^{\circ} \mathrm{C}\right)$ for $\mathrm{T}$ 2 toxin production and can produce this mycotoxin during overwintering under a snow cover in the field and/or during storage (24-26). Among all grains tested so far, corn, wheat, barley, oat, and rye are most frequently contaminated with this mycotoxin (3).

Compared to the related mycotoxin deoxynivalenol, $\mathrm{T}-2$ toxin is less frequent in grain and other agricultural products $(3,8,27)$. According to the EU reports, type $B$ trichothecenes such as deoxynivalenol, nivalenol and fusarenon $\mathrm{X}$ are more frequent $(57 \%, 16 \%$ and $10 \%$ of tested grain samples) in European grain samples than type A trichothecenes. However, T-2 toxin is the most common type A mycotoxin ( $20 \%$ of tested samples), while other toxins of this group are less common: HT-2 toxin (14\%), T-2 tetraol (6\%), neosolaniol (1\%), diacetoxyscirpenol (DAS) (4\%), monoacetoxyscirpenol (MAS) (1\%). Average T-2 toxin mass fraction in grain ranges between $0.03 \mathrm{mg} \mathrm{kg}^{-1}$ and $0.155 \mathrm{mg} \mathrm{kg}^{-1}(3,28-30)$. A similar incidence of T-2 toxin in grain (13\% to $30 \%$ ) with the average mass fraction from $0.01 \mathrm{mg} \mathrm{kg}^{-1}$ to $0.71 \mathrm{mg} \mathrm{kg}^{-1}$ has been reported by other authors $(26,31,32)$. In contrast, reports by Haubruge et al. (33) and Rasmussen et al. (20) indicate high incidence of T-2 toxin in grain samples (65\% to $76 \%$ ) with average mass fraction from $0.01 \mathrm{mg} \mathrm{kg}^{-1}$ to $0.1 \mathrm{mg} \mathrm{kg}^{-1}$ and maximum value of $3.75 \mathrm{mg} \mathrm{kg}^{-1}$. Sample contamination this high was in a direct relationship with the climate (samples from a warm climate and samples collected after rainy summer period, respectively).

In Croatia in 1988, T-2 toxin and related toxin diacetoxyscirpenol were present in $53.5 \%$ of poultry feed samples in the level from $0.1 \mathrm{mg} \mathrm{kg}^{-1}$ to $0.2 \mathrm{mg} \mathrm{kg}^{-1}$ (34). In a ten-year period (1989-1998) T-2 toxin was found in $18 \%$ of tested samples (35-37). Between 1998 and 2004, T-2 toxin was detected in $16.8 \%$ of tested samples (grain and poultry feed) in mass fractions from $0.1 \mathrm{mg} \mathrm{kg}^{-1}$ to $0.7 \mathrm{mg} \mathrm{kg}^{-1}$. In comparison, other related toxins such as diacetoxyscirpenol and deoxynivalenol were detected in $27.6 \%$ and $41.2 \%$ of the tested samples, respectively, and the levels of these toxins ranged from $0.1 \mathrm{mg} \mathrm{kg}^{-1}$ to $1.2 \mathrm{mg} \mathrm{kg}^{-1}$ and from $0.05 \mathrm{mg} \mathrm{kg}^{-1}$ to $3.44 \mathrm{mg} \mathrm{kg}^{-1}$, respectively (38).

\section{Toxicity of T-2 toxin in poultry}

The toxicity of the T-2 toxin and related mycotoxins can be affected by a variety of factors such as administration route, time of exposure, the number of exposures, dose, animal's age, sex and overall health, and presence of other mycotoxins (39-41). The 
12,13-epoxide ring of T-2 toxin is responsible for its toxic activity and de-epoxidation results in the loss of any apparent toxicity. Furthermore, toxicity is lowered by deacetylation during which HT-2 toxin is produced as the first metabolite, while the final product of this reaction is scarcely toxic $\mathrm{T}-2$ tetraol $(8,11,15,16$, 42). A dose T-2 toxin that would kill $50 \%$ of a sevenday-old broiler population $\left(\mathrm{LD}_{50}\right)$ is $4.97 \mathrm{mg} \mathrm{kg}^{-1}$. In comparison with other mycotoxins in seven-dayold broilers, T-2 toxin is more toxic than aflatoxin $\left(\mathrm{LD}_{50}=6.8 \mathrm{mg} \mathrm{kg}^{-1}\right)$, HT-2 toxin $\left(\mathrm{LD}_{50}=7.22 \mathrm{mg}\right.$ $\left.\mathrm{kg}^{-1}\right)$, scirpentriol $\left(\mathrm{LD}_{50}=9.33 \mathrm{mg} \mathrm{kg}^{-1}\right)$, neosolaniol $\left(\mathrm{LD}_{50}=24.87 \mathrm{mg} \mathrm{kg}^{-1}\right), \mathrm{T}-2$ tetraol $\left(\mathrm{LD}_{50}=33.79 \mathrm{mg}\right.$ $\left.\mathrm{kg}^{-1}\right)$, and deoxynivalenol $\left(\mathrm{LD}_{50}=140 \mathrm{mg} \mathrm{kg}^{-1}\right)$, and is equally or less toxic than ochratoxin $\left(\mathrm{LD}_{50}=2.1 \mathrm{mg}\right.$ $\left.\mathrm{kg}^{-1}\right)$ and diacetoxyscirpenol $\left(\mathrm{LD}_{50}=2.0 \mathrm{mg} \mathrm{kg}^{-1}\right.$ to $\left.5.9 \mathrm{mg} \mathrm{kg}^{-1}\right)(8,43)$. The lethal dose of T-2 toxin in feed during a feeding period of seven days is about $10 \mathrm{mg} \mathrm{kg}^{-1}$ of chicken body weight (44).

\section{Mechanism of action}

After exposure by the oral, dermal or inhalation route, T-2 toxin can cause severe effects in various animal organs and tissues. So far, toxic effects have been evidenced in the cells of fungi, protozoa, insects, moulds, plants, and different cell cultures (39-41, 45-47). In poultry, the toxic effects of T-2 toxin can be classified as genotoxic and cytotoxic, immunomodulatory effects, effects on the cells of the digestive system and liver, effects on the nervous system and skin and impairment of poultry performance.

\section{Genotoxic and cytotoxic effects}

T-2 toxin inhibits DNA, RNA, and protein synthesis in eukaryotic cells, affects the cell cycle, and induces apoptosis both in vivo and in vitro $(2,3,5,48-51)$. The chemical structure of T-2 toxin molecule (position of chemical groups on the trichothecene ring) again has an essential role that determines the mode and target of action, because it specifies the interaction with protein molecule. Thus T-2 toxin, like HT-2 toxin and diacetoxyscirpenol, inhibits polypeptide chain initiation, while other trichothecenes affect elongation (trichothecin) and termination (deoxynivalenol) (5254). The mechanism of action resembles the action of certain antibiotics (lincosamides, streptogramins, macrolide antibiotics) on bacterial cells (55).

Cytotoxic effects of toxin have been reported in lymphoid cells (52), while induction of DNA strand breaks caused impairment of the immune system ( 56 , 57). Highly sensitive to $T-2$ toxin activity are actively dividing cells (cells of the gastrointestinal tract, bone marrow, lymph nodes, spleen, and liver). Cytotoxic radiomimetic effects of T-2 toxin are considered to be a result of primarily impaired protein synthesis, and consequently of the inhibition of DNA and RNA synthesis $(8,58,59)$. Furthermore, in vivo T-2 toxin can induce polyploidy in Allium cepa (60), sex-linked recessive lethal mutations in Drosophila melanogaster (61), DNA single-strand breaks in thymus and spleen of BALB/c mouse (56), chromosomal aberrations in Chinese hamster bone marrow and mice $(62,63)$, and DNA damage in chicken peripheral lymphocytes (64). According to the results of studies on the genotoxicity of T-2 toxin in vitro, T-2 toxin can induce DNA single-strand breaks in primary hematocytes, thymic and spleen lymphocytes of BALB/c mouse (56), gene mutations and sister chromatide exchange in Chinese hamster V79 fibroblasts (65-68), formation of micronucleus in Chinese hamster V79 fibroblasts (67), unscheduled DNA synthesis in human fibroblasts (69), and inhibition of intercellular communication in Chinese hamster V79 cells (70). In addition, T-2 toxin and related mycotoxins can induce apoptosis in vitro $(49,71,72)$ and in vivo in haematopoietic tissue, spleen, liver and intestinal crypts of mice (73-76). In chicken, apoptosis was detected in the thymus, but not in the spleen (57). T-2 toxin induces apoptosis depending on the activation of JNK and p38 MAP kinases, but the precise mechanism has not yet been elucidated.

\section{Effects on the immune system}

T-2 toxin is a mycotoxin with immunomodulatory activity, e.g. it can stimulate (immunostimulation) or inhibit (immunosupression) the activity of the immune system. Its mode of action is time- and dosedependent. Immunosupression is the result of action of high doses that cause damage to the bone marrow, lymph nodes, spleen, thymus and intestinal mucose, leucopenia and consequently increased susceptibility to infection with pathogens (Listeria monocytogenes and Salmonella sp.) $(13,72,77)$. On the other hand, immunostimulation is caused by low doses of the toxin, and is evidenced by increased serum IgA and $\operatorname{IgE}$ antibodies because of rapid and transient activation of the genes responsible for the function of the immune system as well as genes important for inflammation response $(59,72,78,79)$. 
Immunotoxicity of type A trichothecene (especially of T-2 toxin) is significantly lower than that of type Btrichothecenes (80). However, T-2 toxin can induce necrosis and depletion of lymphoid cells in the thymus, spleen, and lymph nodes of chicken and pullets $(50,81,82)$. Exposure of chicken to T-2 toxin caused increased mortality by Salmonella infection $(44,83)$, lower antibody titres against Newcastle disease, and infectious bursal disease (84-85). Although molecular and cellular mechanisms of action of T-2 toxin and other mycotoxins (aflatoxin, ochratoxin and related trichothecenes) are quite different, immunosuppressive effects are the result of direct or indirect inhibition of protein synthesis (59). Since most of the research on T-2 toxin effects on the immune system has been done on laboratory animals, evaluation of possible effects in poultry still needs to be explained.

\section{Effects on the digestive system and liver}

T-2 toxin can have toxic effects on almost all cellular processes in the digestive system. Even a small dose of the toxin can damage the mucosa of the digestive tract and impair resorption of nutrients. Necrotic damages have been detected in the mouth (86), gizzard tissue, intestinal mucosa and liver $(87,88)$. Necrotic lesions in the digestive tract are characterised by white-yellowish mucosal bulge containing caseous-necrotic material (89). Lesions in the mouth and decreased average daily gain in poultry are detected after a single application of the toxin in the dose of $5 \mathrm{mg} \mathrm{kg}^{-1}$, but more frequently after longterm feeding with contaminated feed $\left(1 \mathrm{mg} \mathrm{kg}^{-1}\right.$ to $\left.5 \mathrm{mg} \mathrm{kg}^{-1}\right)$ for at least one week $(90,91)$. Other type-A trichothecenes such as HT-2 toxin, diacetoxyscirpenol, monoacetoxyscirpenol and scirpentriol $(50,86)$ can also cause these above mentioned lesions. T-2 toxin and related trichothecenes are quickly absorbed in the intestinal tract, metabolised, and eliminated almost completely (80\% to $90 \%$ ) within 48 hours (92-94). However, their toxic effect can be increased by enterohepatic recirculation (8). Detoxification of T-2 toxin and related trichothecens by intestinal microflora has not been demonstrated in poultry (95).

The main target of the toxic effects of T-2 toxin in vivo is the liver. Inhibition of protein synthesis reduces the activity of the enzymes necessary for the metabolism of toxic substances, induces lipid peroxidation, and increases the activity of glutation reductase (96). However, these changes in enzyme activity are usually not dose- and time dependent, and are not useful as biomarkers for the differential diagnosis of T-2 toxicosis and other disorders.

\section{Effects on the nervous system and skin}

$\mathrm{T}-2$ toxin and deoxynivalenol act as neurotoxins by damaging the blood-brain barrier (97). Changes such as the loss of appetite, muscular coordination problems, and vomiting (characteristic for deoxynivalenol) have been detected in animals that were eating feed contaminated with trichothecenes $(50,81,98)$. These are explained by neuro-chemical changes in the brain and changes in the activity of serotonine. Serotonine synthesis in the brain depends on the amino acid triptophan and enzyme triptophan-hydroxylase. Since the concentration of tryphtophan correlates with the concentration of neutral amino acids in the blood, it is assumed that increased blood amino acid concentrations, caused by the inhibition of protein synthesis in the liver and other tissues, increase the concentration of tryptophan in the brain. Consequently, serotonine synthesis and activation of serotonergic neurons are also increased (96). In addition, there is evidence of dopamine concentration increase and a decrease in norepinefrine concentration. All these neural disorders have only been detected in a small number of animals $(50,98)$.

Dermotoxic effects of T-2 toxin are characterised as necrohaemorrhagic dermatitis. Some animals showed depigmentation of the skin of the legs and comb cyanosis. Very low feather quality and abnormal position of the wings were found in animals that consumed feed contaminated with high levels of T-2 toxin $\left(4 \mathrm{mg} \mathrm{kg}^{-1}\right.$ to $\left.16 \mathrm{mg} \mathrm{kg}^{-1}\right)(50,99)$.

\section{Effects on poultry performance}

Symptoms of T-2 toxicosis are nearly the same as of the toxicosis caused by other trichothecenes. Usually the differences are only in the extent and severity of changes. First visual signs of the poisoning with T-2 toxin are lower feed intake, reduced weight gain and growth retardation (50, 99, 100). Laying hens had lower egg production (101), lower egg and shell weight and thinner egg shells and decreased hatchability $(99,100)$. Lower egg production was detected at the dose of $1 \mathrm{mg} \mathrm{kg}^{-1}$ of T-2 toxin (12.5\%), while the dose of $5 \mathrm{mg} \mathrm{kg}^{-1}$ and $10 \mathrm{mg} \mathrm{kg}^{-1}$ led to a decrease of $68 \%$ and $78.9 \%$, respectively. Changes in the quality of egg shell were detected only at a high toxin level of $20 \mathrm{mg} \mathrm{kg}^{-1}$ (102). 
In brief, the following symptoms may indicate the onset of potential poisoning with T-2 toxin: decreased feed intake, growth inhibition with (s)lower weight gain, mouth lesions and depigmentation of the leg skin, changed feather quality, and neural disturbances. In laying hens, poisoning is indicated by reduced egg production (with thinner egg shell), decreased hatchability, reduced feed intake, cyanosis of the comb, leucopoenia, and changed feather quality. A conclusive diagnosis is based on anamnesis, clinical and pathological analysis, and detection of characteristic necrotic lesions in the mouth, crop, gizzard, intestinal mucosa and the liver (50).

\section{Regulatory measures and recommendations}

In the countries of the European Union, a new monitoring scheme is in use that can detect T-2 toxin and other mycotoxins in cereals and their products. Several guidelines have also been issued which include recommended levels for deoxynivalenol $\left(0.9 \mathrm{mg} \mathrm{kg}^{-1}\right.$ to $\left.12 \mathrm{mg} \mathrm{kg}^{-1}\right)$ and fumonisins $\left(1 \mathrm{mg} \mathrm{kg}^{-1}\right.$ to $50 \mathrm{mg}$ $\left.\mathrm{kg}^{-1}\right)$ for various feed and animal species $(103,104)$. Since data about the occurrence and toxic effects of T-2 and HT-2 toxin are missing, there are no specific regulations or recommendations of The European Commission about the maximal concentrations in products intended for animal feed. Some other countries have set their guidance values for T-2 toxin in products intended for animal feed. In Ukraine these levels for all trichothecenes are $0.2 \mathrm{mg} \mathrm{kg}^{-1}$ in combined feed for layers and broilers and $0.25 \mathrm{mg} \mathrm{kg}$ ${ }^{1}$ in feed for calves and older cattle fed for beef) and in Serbia and Montenegro $0.3 \mathrm{mg} \mathrm{kg}^{-1}$ in feed for chickens and pigs and $0.6 \mathrm{mg} \mathrm{kg}^{-1}$ in feed for swine, cattle, and other poultry). In China, T-2 toxin limit in complete feed for all animals is $0.08 \mathrm{mg} \mathrm{kg}^{-1}$. A limit of $0.1 \mathrm{mg} \mathrm{kg}^{-1}$ for T-2 toxin has been set in Israel for all grain and in Iran for complete feed intended for sheep, goats and beef cattle. Complete feed intended for calves, lambs, kids, dairy sheep, goats and cattle in Iran has a limit of only $0.025 \mathrm{mg} \mathrm{kg}^{-1}$ of T-2 toxin. In Canada, feed for swine and poultry can contain up to $1.0 \mathrm{mg} \mathrm{kg}^{-1}$ of T-2 toxin, while feed for cattle and poultry has also a limit of $0.1 \mathrm{mg} \mathrm{kg}^{-1}$ of HT-2 toxin (105). In Croatia, maximal allowed level of T-2 toxin, including its derivative HT-2, in complete and supplemental feed for pigs, poultry and calves is $0.5 \mathrm{mg} \mathrm{kg}^{-1}$ (106).

In conclusion, guidance levels, if there are any, vary a lot between countries, and regulations are partial. Mycotoxin contamination of grain and feed and the ensuing consumption of these ingredients by animals is an inevitable part of animal production systems. Contamination may be avoided by the use of mould-resistant crops, application of agro-technical measures, and decontamination of food and feed (107-109). It is also recommended that in a case of poisoning, the feed should be completely withdrawn as it can result in fast health improvement. Detection of mycotoxins in feed (representative sample) of sick animals can help the diagnosis. Bear in mind however that detection of moulds in grain, feed, and food is not a proof of mycotoxin contamination, but a sensitive indicator of potential contamination (8). According to the collected data on the occurrence, toxicity, metabolism in animals, and clinical signs of toxicosis in poultry, it has been estimated that the total amount of all of trichothecenes, including T-2 toxin, in poultry feed should not exceed $0.5 \mathrm{mg} \mathrm{kg}^{-1}$ (110). It is therefore advisable to at least monitor the occurrence of T-2 toxin and to use this level as guidance when toxicosis is suspected.

Moreover, mycotoxins represent a public health concern. Several reports have associated outbreaks of human disease with the presence of thichothecenes in food $(40,41)$. Additionally, animals consuming contaminated feed can indirectly pose a threat for humans because of potentially present residues of these toxins in animal-derived food products. As genotoxicity and cytotoxicity data indicate that $\mathrm{T}-2$ toxin is highly toxic, and as it is widespread in cereals and food, additional research of its toxic potential in animals and in humans is necessary.

\section{Acknowledgment}

This investigation was supported by the Croatian Ministry of Science, Education and Sports (grant No. 0022-0222148-2125).

\section{REFERENCES}

1. Desjardins AE, Hohn TM, McCormick SP. Trichothecene biosynthesis in Fusarium species: chemistry, genetics, and significance. Microbiol Mol Biol Rev 1993;57:595604.

2. European Commission (EC). Opinion of the Scientific Committee on Food on Fusarium-toxins Part 5: T-2 toxin and HT-2 toxin, 2001 [displayed 23 November 2007]. Available at http://ec.europa.eu/food/fs/sc/scf/ out88_en.pdf. 
3. European Commission (EC). Reports on tasks for scientific co-operation. Collection of occurrence data of Fusarium toxins in food and assessment of dietary intake by the population of EU Member States, 2001 [displayed 23 November 2007]. Available at http:// ec.europa.eu/food/fs/scoop/task3210.pdf.

4. Krska R, Baumgartner S, Josephs R. The stateof-the-art in the analysis of type-A and type-B tricothecene mycotoxins in cereals. Fres $\mathrm{J}$ Anal Chem 2001;371:285-99.

5. Rocha O, Ansari K, Doohan FM. Effects of trichothecene mycotoxins on eukaryotic cells: a review. Food Addit Contam 2005;22:369-78.

6. Zöllner P, Mayer-Helm B. Trace mycotoxins analysis in complex biological and food matrices by liquid chromatography-atmospheric pressure ionisation mass spectrometry. J Chromatogr A 2006;1136:12369.

7. Uleno Y. Trichothecenes: overview address. In: Rodricks JV, Hesseltine DW, Mehlman MA, editors. Mycotoxins in Human and Animal Health. Park Forest South, Illinois, USA: Pathotox Publishers; 1977. p. 189-207.

8. Leeson S, Diaz G, Summers JD. Poultry Metabolic Disorders and Mycotoxins. Ontario, Canada: University Books; 1995.

9. Burmeister HR, Ellis JJ, Yates SG. Correlation of biological to chromatographic data for two mycotoxins elaborated by Fusarium. Appl Microbiol 1971;21:6735.

10. Desjardins AE, Plattner RD, Vandmiddlesworth F. Trichothecene biosynthesis in Fusarium sporotrichioides: origin of the oxygen atoms of T-2 Toxin. Appl Environ Microbiol 1986;51:493-7.

11. Wannemacher RW, Wiener SL. Trichothecene mycotoxins. In: Zajtchuk R, editor. Textbook Of Military Medicine. Washington DD, USA: Walter Reed Army Medical Center; 1997. p. 655-76.

12. Bottalico A, Perrone G. Toxigenic Fusarium species and mycotoxins associated with head blight in small-grain cereals in Europe. Eur J Plant Pathol 2002;108:61124.

13. Moss MO. Mycotoxin review - 2. Fusarium. Mycologist 2002; 16:158-61

14. Kosiak B, Torp N, Skjerve E, Thrane U. The Prevalence and distribution of Fusarium species in Norwegian cereals: a survey. Acta Agric Scand Sec B 2003;53:16876.

15. Betina V. Mycotoxins, Production, Isolation, Separation and Purification. Amsterdam: Elsevier Science Publishers BV; 1984.

16. Shepard MJ, Gilbert J. Long-Term storage stability of deoxynivalenol standard reference solutions. J Agric Food Chem 1988;36:305-8.

17. Beeton S, Bull AT. Biotransformation and detoxification of T-2 Toxin by soil and freshwater bacteria. Appl Environ Microbiol 1989;55:190-7.
18. Jesenska Z, Sajbidorova J. T-2 toxin degradation by micromycetes. J Hyg Epidemiol Microbiol Immunol 1991;35:41-9.

19. Mateo JJ, Mateo R, Jimenez M. Accumulation of type A trichothecenes in maize, wheat and rice by Fusarium sporotrichiides isolates under diverse culture conditions. Int J Food Microbiol 2002;72:115-23.

20. Rasmussen PH, Ghorbani F, Berg T. Deoxynivalenol and other Fusarium toxins in wheat and rye flours on the Danish market. Food Addit Contam 2003;20:396404.

21. Bergers WWA, van der Stap JGMM, Kientz CE. Trichothecene production in liquid stationary cultures of Fusarium tricinctum NRRL 3299 (Synonym: F. sporotrichioides): comparison of quantitative brine shrimp assay with physicochemical analysis. Appl Environ Microbiol 1985;50:656-62.

22. D'Mello JPF, Placinta CM, Macdonald AMC. Fusarium mycotoxins: a review of global implications for animal health, welfare and productivity. Anim Feed Sci Technol 1999;80:183-205.

23. Homdork S, Fehrmann H, Beck R. Influence of different storage conditions on the mycotoxin production and quality of Fusarium-infected wheat grain. J Phytopathol 2000;148:7-15.

24. Cullen D, Smalley EB, Caldwell RW. New process for T-2 toxin production. Appl Environ Microbiol 1982;44:371-5.

25. Park JJ, Chu FS. Immunochemical analysis of trichothecenes produced by various fusaria. Mycopathologia 1993;121:179-92.

26. Park JJ, Smalley EB, Chu FS. Natural occurrence of Fusarium mycotoxins in field samples from the 1992 Wisconsin corn crop. Appl Environ Microbiol 1996;62:1642-8.

27. Murphy PA, Hendrich S, Landgren C, Bryant CM. Food mycotoxins: an update. J Food Sci 2006;71:R51-65.

28. Gareis M, Bauer J, Enders C, Gedek B. Contamination of cereals and feed with Fusarium mycotoxins in European countries. In: Chelkowski J, editor. Fusarium mycotoxins, taxonomy and pathogenicity. Vol. 2. Amsterdam: Elsevier Science Publishers BV; 1989. p. 441-72.

29. Langseth W, Rundberget T. The occurrence of HT-2 toxin and other trichothecenes in Norwegian cereals. Mycopathologia 1999;147:157-65.

30. Schollenberger M, Müller HM, Rüfle M, Suchy S, Plank S, Drochner W. Natural occurence of 16 Fusarium toxins in grains and feedstuffs of plant origin from germany. Mycopathologia 2006;161:43-52.

31. Kawamura O, Satoshi N, Sonomi S, Ohtani K, Yoshitugu S, Tanaka T, Ueno Y. Survey of T-2 toxin in cereals by an indirect enzyme linked immunosorbent assay. Food Agric Immunol 1990;2:173-80. 
32. Perkowski J, Basinski T. Natural contamination of oat with group A trichotecenes mycotoxins in Poland. Food Addit Contam 2002;19:478-82.

33. Haubruge E, Chasseur C, Suetens C, Mathieu F, Begaux F, Malaisse F. Mycotoxins in stored barley (Hordeum vulgare) in Tibet Autonomous Region (People's Republic of China). Mount Res Develop 2003;23:284-7.

34. Beker D. Prisutnost T-2 toksina i diacetoksiscirpenola u krmivima i smjesama za perad. Vet Arhiv 1988;58:1337.

35. Brlek V, Pavičić P, Vedrina J. Prisutnost fuzarijskih plijesni i nekih njihovih mikotoksina u žitaricama namijenjenih hranidbi životinja. Krmiva 1999;41:195-9.

36. Pavičić P, Brlek V, Nemanič A. Učestalost fuzarijskih mikotoksina u krmnim smjesama: 1989-1998. Krmiva 1999;41:183-8.

37. Pepeljnjak S, Šegvić M. An Overview of mycotoxins and toxigenic fungi in Croatia. In: Logrieco A, Visconti A, editors. An Overview on Toxigenic Fung and Mycotoxins in Europe. Dordrecht: Kluwer Academic Publishers; 2004. p. 33-50.

38. Sokolović M, Šimpraga B. Survey of trichothecene mycotoxins in grains and animal feed in Croatia by thin layer chromatography. Food Control 2006;17:733-40.

39. Joint Expert Committee on Food Additives (JECFA). T-2 and HT-2 toxins. Monographs $\&$ Evaluations No. 47, 2001 [displayed 23 November 2007]. Available at http://www.inchem.org/documents/jecfa/jecmono/ v47je06.htm.

40. World Health Organization (WHO). Selected Mycotoxins: Ochratoxin, Trichothecenes, Ergot. Environmental Health Criteria 105, 1990 [displayed 23 November 2007]. Available at http://www.inchem.org/documents/ ehc/ehc/ehc105.htm.

41. World Health Organization (WHO). Evaluation of certain mycotoxins in food. WHO Techn Rep Ser 906. Geneva: WHO; 2002.

42. Meek IB, Peplow AW, Ake C, Phillips TD, Beremand MN. Tri1 encodes the cytochrome P450 monooxygenase for C-8 hydroxylation during trichothecene biosynthesis in Fusarium sporotrichioides and resides upstream of another new tri gene. Appl Environ Microbiol 2003;69:1607-13.

43. Ožegović L, Pepeljnjak S. Mikotoksikoze. Zagreb: Školska knjiga; 1995.

44. Hoerr FJ, Carlton WW, Yagen B, Joffe AZ. Mycotoxicosis caused by either T-2 toxin or diacetoxyscirpenol in the diet of broiler chickens. Fund Appl Toxicol 1982;2:1214.

45. Beasley VR, Swanson SP, Corley RA, Buck WB, Koritz GD, Burmeister HR. Pharmacokinetics of the trichothecene mycotoxin, T-2 toxin, in swine and cattle. Toxicon 1986;24:13-23.

46. International Agency for Research on Cancer (IARC). Monographs on the Evaluation of the Carcinogenic
Risk of Chemicals to Humans. Some Naturally Occurring Substances: Food Items and Constituents, Heterocyclic Amines and Mycotoxins. Lyon: IARC Press; 1993.

47. Rotter B, Prelusky DB, Petska JJ. Toxicology of deoxynivalenol (vomitoxin). J Toxicol Environ Health 1996;48:1-34.

48. Kiessling KH. Biochemical mechanism of action of mycotoxins. Pure Appl Chem 1986;58:327-38.

49. Uleno Y, Umemori K, Niimi EC, Tanuma S, Nagata SI, Sugamata M, Ihara T, Sekijima M, Kawai KI, Ueno I. Induction of apoptosis by T-2 toxin and other natural toxins in HL-60 human promyelotic leukemia cells. Nat Toxins 1995;3:129-37.

50. Hoerr FJ. Mycotoxicoses. In: Saif YM, editor. Diseases of Poultry. $11^{\text {th }}$ ed. Ames, Iowa, USA: Iowa State University Press; 2003. p. 1103-32.

51. Sudakin DL. Trichothecenes in the environment: relevance to human health. Toxicol Lett 2003;143:97107.

52. Cundliffe E, Cannon M, Davies J. Mechanism of inhibition of eukaryotic protein synthesis by trichothecene fungal toxins. Proc Natl Acad Sci USA 1974;71:30-4.

53. Smith KE, Cannon M, Cundliffe E. Inhibition at the initiation level of eukaryotic protein synthesis by T-2 toxin. FEBS Lett 1975;50:8-12.

54. Cundliffe E, Davies JE. Inhibition of initiation, elongation, and termination of eukaryotic protein synthesis by trichothecene fungal toxins. Antimicrob Agents Chemother 1977;11:491-9.

55. Jimenez A, Vazquez D. Quantitative binding of antibiotics to ribosomes from a yeast mutant altered on the peptidyl-transferase center. Eur $\mathrm{J}$ Biochem 1975;54:483-92.

56. Lafarge-Frayssinet C, Decloitre F, Mousset S, Martin M, Frayssinet $C$. Induction of DNA single strand breaks by T2 toxin, a trichothecene metabolite of Fusarium, effect on lymphoid organs and liver. Mutat Res 1981;88:11523.

57. Venkatesh PK, Vairamuthu S, Balachandran C, Manohar BM, Raj GD. Induction of apoptosis by fungal culture materials containing cyclopiazonic acid and T-2 toxin in primary lymphoid organs of broiler chickens. Mycopathologia 2005;159:393-400.

58. Wei CM, Hansen BS, Vaughan MH, McLaughlin CS. Mechanism of action of the mycotoxin trichodermin, a 12-13-epoxytrichothecene. Proc Natl Acad Sci USA 1974;71:713-17.

59. Corrier DE. Mycotoxicosis: mechanisms of immunosuppression. Vet Immunol Immunopathol 1991;30:73-87.

60. Linnainmaa K, Sorsa M, Ilus T. Epoxytrichothecene mycotoxins as c-mitotic agents in Allium. Hereditas 1979;90:151-6. 
61. Sorsa M, Linssainmaa K, Paittela M, Ilus T. Evaluation of the mutagenicity of epoxytrichothecene mycotoxins in Drosophila melanogaster. Hereditas 1980;92:163-5.

62. Norppa H, Penttila M, Sorsa M, Hintikka EL, Ilus T. Mycotoxin T-2 of Fusarium tricinctum and chromosome changes in Chinese hamster bone marrow. Hereditas 1980;93:329-32.

63. Bilgrami KS, Masood A, Rahman MF. Cumulative effect of T-2 toxin and vitamin $\mathrm{C}$ on chromosomal abnormalities in the bone marrow cells of mice (Mus musculus). Cytobios 1995;81:171-4.

64. Sokolovic M, Garaj-Vrhovac V, Ramic S, Simpraga B. Chicken nucleated blood cells as a cellular model for genotoxicity testing using the comet assay. Food Chem Toxicol 2007;45:2165-70.

65. Thust R, Kneist S, Huehne V. Genotoxicity of Fusarium mycotoxins (nivalenol, fusarenon-X, T-2 toxin and zearalenone) in Chinese hamster V79-E cells in vitro. Arch Geschwulstforschung 1983;53:9-15.

66. Hsia CC, Gao Y, Wu JL, Tzian BL. Induction of chromosome aberrations by Fusarium T-2 toxin in cultured human peripheral blood lymphocytes and Chinese hamster fibroblasts. J Cell Physiol 1986;129:65-72.

67. Zhu GF, Cheng SJ, Li MH. The genotoxic effects of T2 toxin, a trichothecene produced by Fusarium fungi. Acta Biol Exp Sinica 1987;20:129-34.

68. Hsia CC, Wu JL, Lu XQ, Li YS. Natural occurrence and clastogenic effects of nivalenol, deoxynivalenol, 3-acetyl-deoxynivalenol, 15-acetyl-deoxynivalenol, and zearalenone in corn from a high-risk area of esophageal cancer. Cancer Detect Prev 1988;13:79-86.

69. Oldham JW, Allred LE, Milo GE, Kindig O, Capen CC. The toxicological evaluation of the mycotoxins T-2 and T-2 tetraol using normal human fibroblasts in vitro. Toxicol Appl Pharmacol 1980;52:159-68.

70. Jone C, Erickson L, Trosko JE, Chang CC. Effect of biological toxins on gap-junctional intercellular communication in Chinese hamster V79 cells. Cell Biol Toxicol 1987;3:1-15.

71. Sun XM, Zhang XH, Wang HY, Cao WJ, Yan X, Zuo LF, Wang JL, Wang FR. Effects of sterigmatocystin, deoxynivalenol and aflatoxin G1 on apoptosis of human peripheral blood lymphocytes in vitro. Biomed Environ Sci 2002;15:145-52.

72. Pestka JJ, Zhou HR, Moon Y, Chung YJ. Cellular and molecular mechanisms for immune modulation by deoxynivalenol and other trichothecenes: unraveling a paradox. Toxicol Lett 2004;153:61-73.

73. Shinozuka J, Li G, Uletsuka K, Nakayama H, Doi K. Process of the development of T-2 toxin-induced apoptosis in the lymphoid organs of mice. Exp Anim 1997;46:117-26.

74. Islam Z, Nagase M, Ota A, Uleda S, Yoshizawa T, Sakato N. Structure-function relationship of T-2 toxin and its metabolites in inducing thymic apoptosis in vivo in mice. Biosci Biotech Biochem 1998;62:1492-7.

75. Murshedul AM, Nagase M, Yoshizawa T, Sakato N. Thymocyte Apoptosis by T-2 toxin in vivo in mice is independent of fas/fas ligand system. Biosci Biotechnol Biochem 2000;64:210-3.

76. Poapolathep A, Ohtsuka R, Kiatipattanasakul W, Ishigami N, Nakayama H, Doi K. Nivalenol-induced apoptosis in thymus, spleen and peyer's patches of mice. Exp Toxicol Pathol 2002;53:441-6.

77. Bondy GS, Pestka, JJ. Immunomodulation by fungal toxins. J Toxicol Environ Health B Crit Rev 2000;3:10943.

78. Minervini F, Fornelli F, Lucivero G, Romano C, Visconti A. T-2 toxin immunotoxicity on human $B$ and $T$ lymphoid cell lines. Toxicology 2005;210:81-91.

79. Jaradat ZW, Vila B, Marquardt RR. Adverse effects of T-2 toxin on chicken lymphocytes blastogenesis and its protection with Vitamin E. Toxicology 2006;225:90-6.

80. Sharma RP. Immunotoxicity of Mycotoxins. J Dairy Sci 1993;76:892-7.

81. Wyatt RD, Hamilton PB, Burmeister HR. The effects of T-2 toxin in broiler chickens. Poultry Sci 1973;52:18539.

82. Boonchuvit B, Hamilton PB, Burmeister HR. Interaction of T-2 toxin with Salmonella infections of chicken. Poultry Sci 1975;54:1693-6.

83. Ziprin RL, Elissalde MH. Effect of T-2 toxin on resistance to systemic Salmonella typhimurium infection of newly hatched chickens. Am J Vet Res 1990;51:1869-72.

84. Kamalavenkatesh P, Viaramuthu S, Balachandran C, Murali Manohar B, Dhinakar raj G. Immunopathological effect of the mycotoxins cyclopiazonic acid and T-2 toxin on broiler chicken. Mycopathologia 2005;159:273-9.

85. Girish, CK, Devegowda, G. Efficacy of glucomannancontaining yeast product (Mycosorb $\left.{ }^{\circledR}\right)$ and hydrated sodium calcium aluminosilicate in preventing the individual and combined toxicity of alfatoxin and T-2 toxin in commercial broilers. Asian-Aust J Anim Sci 2006;19:877-83.

86. Ademoyero AA, Hamilton PB. Mouth lesions in broiler chickens caused by scirpenol mycotoxins. Poultry Sci 1991;70:2082-9.

87. Ademoyero AA, Hamilton PB. Influence of degree of acetylation of scirpenol mycotoxins on feed refusal by chickens. Poultry Sci 1989;68:854-6.

88. Konjević D, Srebočan E, Gudan A, Lojkić I, Severin K, Sokolović M. A pathological condition possibly caused by spontaneous trichotecene poisoning in Brahma poultry: first report. Avian Pathol 2004;33:377-80.

89. Wyatt RD, Harris JR, Hamilton PB, Burmeister HR. Possible outbreaks of fusariotoxicosis in avians. Avian Dis 1972;16:1123-30.

90. Chi MS, Mirocha CJ. Necrotic oral lesions in chickens fed diacetoxyscirpenol, T-2 toxin and crotocin. Poultry Sci 1978;57:807-8. 
91. Brake J, Hamilton PB, Kittrell RS. Effects of the trichothecene mycotoxin diacetoxyscirpenol on feed consumption, body weight and oral lesions of broiler breeders. Poultry Sci 2000;79:856-63.

92. Chi MS, Robison TS, Mirocha CJ, Swanson SP, Shimoda W. Excretion and tissue distribution of radioactivity from tritium-labeled T-2 toxin in chicks. Toxicol Appl Pharm 1978;45:391-402.

93. Yoshizawa T, Swanson SP, Mirocha CJ. T-2 metabolites in the excreta of broiler chickens administered 3H-labeled T-2 toxin. Appl Environ Microbiol 1980;39:1172-7.

94. Prelusky DB, Hamilton RMG, Trenholm HL, Miller JD. Tissue distribution and excretion of radioactivity following administration of ${ }^{14} \mathrm{C}$-labeled deoxynivalenol to White Leghorn hens. Toxicol Sci 1986;7:635-45.

95. Young JC, Zhou T, Yu H, Zhu H, Gong J. Degradation of trichothecene mycotoxins by chicken intestinal microbes. Food Chem Toxicol 2007;45:136-43.

96. Smith TK. Recent Advances in the Understanding of Fusarium trichothecene mycotoxicoses. J Anim Sci 1992;70:3989-93.

97. Wang J, Fitzpatrick DW, Wilson JR. Effects of T-2 toxin on blood-brain barrier permeability monamine oxidase activity and protein synthesis in rats. Food Chem Toxicol 1998;36:955-61.

98. Wyatt RD, Colwell WM, Hamilton PB, Burmeister HR. Neural disturbances in chickens caused by dietary T-2 toxin. Appl Microbiol 1973;26:757-61.

99. Wyatt RD, Hamilton PB, Burmeister HR. Altered feathering of chicks caused by T-2 toxin. Poultry Sci 1975;54:1042-45.

100. Chi MS, Mirocha CJ, Kurtz HF, Weaver G, Bates F, Shimoda W. Effects of T-2 toxin on reproductive performance and health of laying hens. Poultry Sci 1977;56:628-37.

101. Tobias S, Rajic I, Vanyi A. Effect of T-2 toxin on egg production and hatchability in laying hens. Acta Vet Hung 1992;40:47-54.
102. Pier AC, Richard JL, Cysewski SJ. The implications of mycotoxins in animal disease. J Am Vet Med Assoc 1980;176:719-24.

103. Food and Agriculture Organization (FAO). Report of the $33^{\text {rd }}$ Session of the Codex Committee on Food Additives and Contaminants, 2001 [displayed 23 November 2007]. Available at http://www.fao.org/ docrep/meeting/005/YO474E/ Y0474E00.htm.

104. European Commission (EC). Commission recommendation of 17 August 2006 on the presence of deoxynivalenol, zearalenone, ochratoxin A, T-2 and HT-2 and fumonisins in products intended for animal feeding No 576, 2006 [displayed 23 November 2007]. Available at http://eur-lex.europa.eu/LexUriServ/ LexUriServ.d?uri=OJ:L:2006:229:0007:0009:EN: PDF.

105. Know Mycotoxins. Regulations [displayed 23 November 2007]. Available at http://www.knowmycotoxins.com/ regulations.htm.

106. Pravilnik o nepoželjnim i zabranjenim tvarima u hrani za životinje [Act on undesirable and forbidden substances in animal feed, in Croatian]. Narodne Novine 118/2007.

107. Beaver RW. Decontamination of mycotoxin-containing foods and feedstuffs. Trends Food Sci Technol 1991;2:170-3.

108. Peraica M, Domijan A, Jurjević Ž, Cvjetković B. Prevention of exposure to mycotoxins form food and feed. Arh Hig Rada Toksikol 2002;53:229-37.

109. Diaz GJ, Cortes A, Roldan L. Evaluation of the efficacy of four feed additives against the adverse effects of $\mathrm{T}-2$ toxin in growing broiler chickens. J Appl Poult Res 2005; 14:226-31.

110. Eriksen GS, Pettersson H. Toxicological evaluation of trichothecenes in animal feed. Anim Feed Sci Techol 2004;114:205-39. 


\section{Sažetak}

\section{T-2 TOKSIN - POJAVNOST I TOKSIČNOST U PERADI}

T-2 toksin je najtoksičniji predstavnik trikotecenskih mikotoksina tipa A. On je sekundarni produkt metabolizma plijesni roda Fusarium i često je prisutan u žitaricama i hrani za životinje. Štetni učinci uočeni su u eksperimentalnih životinja i životinja u uzgoju. On se povezuje s pojavom bolesti ljudi od mikotoksikoza. Učinci toksina u peradi su višestruki: inhibicija sinteze proteina, DNA i RNA, citotoksični učinak, imunomodulatorni učinak, oštećenje stanica probavnog sustava, organa i kože, živčani poremećaji te pad proizvodnih karakteristika u uzgoju peradi (slabiji prirast, pad nesivosti i valivosti). Koncentracije T-2 toksina u hrani redovito su vrlo malene, a zbog imunosupresivnog djelovanja toksina te istodobne sekundarne infekcije bolest se često teško dijagnosticira. Pri pojavi bolesti promjenom hrane može doći do poboljšanja zdravstvenog stanja, što također upućuje na moguće trovanje mikotoksinima. Redovita kontrola uzoraka žitarica i hrane za životinje jedna je od preventivnih mjera, a detekcija mikotoksina u žitaricama i hrani pouzdana je samo ako se ispituje reprezentativan uzorak. U radu su opisani učestalost i toksični učinci T-2 toksina u peradi.

KLJUČNE RIJEČI: citotoksičnost, genotoksičnost, trikotecenski mikotoksini, zakonski propisi

CORRESPONDING AUTHOR:

Marijana Sokolović

Heinzelova 55

HR-10000 Zagreb

E-mail: sokolm@hi.t-com.hr 